\title{
Getting the Most out of Social Media: Strategic Practices When Using Social Media ${ }^{1}$
}

\author{
Caroline R. Warwick, Lauri M. Baker, Jessica C. Fernandez, and Joy N. Rumble 2
}

\section{Social Media and Agriculture}

Social media has created an environment for individuals to interact with each other in a two-way communication pattern that has allowed for the creation and maintenance of relationships. Social media has also allowed individual agricultural producers to pursue direct-to-consumer marketing easier than ever before, with $24.3 \%$ of direct-toconsumer sales directly marketed for human consumption through the online marketplace (National Agricultural Statistics Service, 2015). The agricultural industry has ventured into social media seeking these relations with consumers, agriculturalists, and other industry professionals. Because the internet has transformed the traditional model of communication into a more informal and conversational model, it is vital for agriculturalists who are interacting through social media with consumers to be creative and have fun while also maintaining a level of professionalism and appropriateness (Telg \& Irani, 2012).

This EDIS publication is designed for Florida professionals, agriculturalists, organizations, and producers looking to develop a better understanding of social media platforms and get the most out of their social media usage. This publication specifically focuses on 15 practices for strategic social media use.

\section{Strategic Practices When Using Social Media}

1. Keep all posts positive and contribute something of value to your community and brand.

2. Position yourself as the expert. This is what you do for a living; showcase agriculture and your personal story. Don't be afraid to approach difficult topics, explaining how and why you are making choices on the farm.

3. Hold meaningful conversations with followers who want to learn something. A conversation is a two-way street; give consumers an opportunity to voice their opinions, concerns, and feedback. Education can happen through social media engagement in a non-formal way, which may be more impactful than formal education for some stakeholder groups (Rohling et al., 2016).

4. Be productive, not just active. Accomplish your purpose.

5. Quality over quantity. Keep it simple, concise, and meaningful.

6. Do not overdo it. Constant self-promotion is not attractive-share more than just your product.

1. This document is AEC561, one of a series of the Department of Agricultural Education and Communication, UF/IFAS Extension. Original publication date August 2015. Revised July 2021. Visit the EDIS website at https://edis.ifas.ufl.edu for the currently supported version of this publication.

2. Caroline R. Warwick, science communication specialist, UF/IFAS Mid-Florida Research and Education Center, Apopka, FL; Lauri M. Baker, associate professor, Department of Agricultural Education and Communication; Jessica C. Fernandez, former graduate student, Department of Agricultural Education and Communication; and Joy Rumble, former assistant professor, Department of Agricultural Education and Communication, UF/IFAS Center for Public Issues Education in Agriculture and Natural Resources; UF/IFAS Extension, Gainesville, FL 32611.

The Institute of Food and Agricultural Sciences (IFAS) is an Equal Opportunity Institution authorized to provide research, educational information and other services

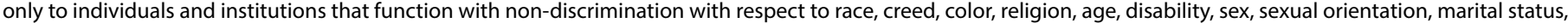

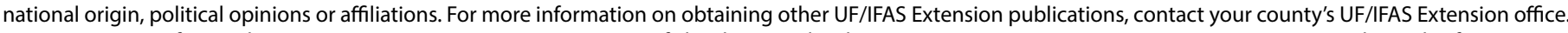
U.S. Department of Agriculture, UF/IFAS Extension Service, University of Florida, IFAS, Florida A \& M University Cooperative Extension Program, and Boards of County Commissioners Cooperating. Nick T. Place, dean for UF/IFAS Extension. 
7. Be open and honest at all times. Consumers want to be able to trust you. This is your chance to show them that you are not only dedicated to providing them with top-quality products, but also your commitment to excellent customer service. This is the number one thing consumers want from you, so give it to them. You have nothing to hide. Consumers have even gone as far as to change their opinion on controversial agricultural issues after transparent experiences with farmers (Stebner et al., 2015).

8. Take time to build relationships and trust. Social media gives you the opportunity to connect with consumers in a new way. Take advantage of the two-way communication channel that you and your consumers have access to and build a relationship by including them and responding to posts or questions they may have. This relationship will not happen overnight. Be patient. Just because you have followers does not mean they will listen. Give them a reason and time to listen (Stebner et al., 2017).

9. Be willing to adapt. Technology is ever-changing. If something is not working, try something new. Ask you audience what they want to see and continually seek new ways to reach your audience through technology (Baker et al., 2020).

\section{Engage to enrich your presence. Engagement for} engagement's sake is not efficient. Contribute something that is sincere and of value to your consumers, such as trivia about your product(s) or fun facts about your farm's history. Your followers want to feel like they get something extra or special by following you (Stebner et al., 2017).

11. Invoke multiple senses. Multiple platforms and multiple ways of posting information can grab different individuals' attention. Use it to your advantage. Social media allows you to post not only words, but also pictures and videos. Use them all to engage with consumers and appeal to individuals' preferred senses (Baker et al., 2020).

12. Always follow up with connections. Social media allows you and consumers to connect through two-way communication. Take advantage of this and make followers feel special. A quick response to a follower's post can really make a difference.

13. Mind your manners. ALWAYS. Sometimes followers are not always polite, but let them speak their mind and respond in an appropriate manner. Other followers will see this in a positive light and will most likely respect you and your business more because you were polite.

14. Listen to others on social media. With billions of individuals on social media and millions of firms now also joining, the feedback provided through the different platforms and the ideas one can gain from viewing others' sites can allow you to learn something new, too.

15. Most importantly, have fun! Social media is a marketing tool. Be creative and purposeful in your communication with your followers.

\section{Summary}

Social media attracts broad audiences from children to senior citizens. You want your social media presence to be appropriate for everyone to view, share, and learn something from. Keep these practices in mind, and you should be on your way to having a great social media presence.

For more information on getting the most out of social media, be sure to check out these other publications from faculty housed in the UF/IFAS Center for Public Issues Education in Agriculture and Natural Resources:

- Getting the Most out of Social Media: What is Social Media?

- Getting the Most out of Social Media: How to Successfully Use Social Media

- Getting the Most out of Social Media: Good Practices When Using Social Media

- Storytelling through Social Media (AEC 556)

- Story Development (AEC 553)

- Face-to-Face Storytelling (AEC 555)

- Letting Them In: Sharing Your Story with People outside of Your Industry (AEC 554)

\section{References}

National Agricultural Statistics Service

(2015). https://quickstats.nass.usda.gov/ results/0154AEB5-EC04-3CAA-9202-B20F330AAF8E

Baker, L. M., Tully, K. M., Sumners, D. R., Jones, E. F., LeónReyes, A. E., Boyer, C. R., \&, Peterson, H. H. (2020). Is it for generation me? A qualitative study exploring marketing and selling plants online to millennial-aged consumers. Journal of Applied Communications, 104(2). https://doi. org/10.4148/1051-0834.2289 
Rohling, K., Wandersee, C., Baker, L. M., \& Tomlinson, P. (2016). Communicating Climate Change: A Qualitative Study Exploring how Communicators and Educators are Approaching Climate-Change Discussions. Journal of Applied Communication, 100(2). https://doi. org/10.4148/1051-0834.1232

Stebner, S., Ray, J., Becker, J., \& Baker, L. M. (2015). Totally transparent: A qualitative study about the impact of farm tours on bloggers. Journal of Applied Communications, 99(4), 48-61. https://doi.org/10.4148/1051-0834.1059

Stebner, S., Baker, L. M., Boyer, C. R., \& Peterson, H. H. (2017) Marketing with more: An in-depth look at relationship marketing with new media in the green industry, Journal of Applied Communications, 101(2). http://newprairiepress.org/jac/vol101/iss $2 / 2$

Telg, R., \& Irani, T. (2012). Agricultural communications in action: A hands-on approach (1st ed.). Clifton Park, NY: Delmar, CENGAGE Learning. 